\title{
Proteins in Pulses
}

\author{
Anjana Agarwal* \\ Nutritionist and Aromatherapist, SNDT Women's University, Mumbai, India \\ *Corresponding author: Dr. Anjana Agarwal, Nutritionist and Aromatherapist, SNDT Women's University, Mumbai, India, Tel: +919958593488; E-mail: \\ dranjanaagarwal@gmail.com
}

Received date: December 30, 2016; Accepted date: December 30, 2016; Published date: January 07, 2017

Copyright: ( 2017 Agarwal A, et al. This is an open-access article distributed under the terms of the Creative Commons Attribution License, which permits unrestricted use, distribution, and reproduction in any medium, provided the original author and source are credited.

Citation: Agarwal A (2017) Proteins in Pulses. J Nutr Disorders Ther 7: e129. doi:10.4172/2161-0509.1000e129

\section{Editorial}

Proteins are vital for health. They act like saviour of each cell by participating in all anabolic as well catabolic processes in the body. They are known to build the muscle mass and repair the damaged cells. However, the human body has limited capacity to store excess protein hence need regular supply from dietary sources. Primarily proteins are made up of a series of amino acids. Some are essential amino acids which have to be obtained from food. Different food sources contain many amino acids in different proportions. It is the amino acid profile which determines the quality of protein or the biological value of the food [1]. Usually animal protein contains all essential amino acids thus considered a good quality protein. Plant proteins in one food sources usually do not contain all the essential amino acids.

Among plant proteins, pulses are very rich in protein and provide many essential amino acids except methionine and cysteine in sufficient quantity hence complemented by cereals which are high in these amino acids. Different pulses contain different amino acid profile which varies significantly in different genotypes within species, geographical location and environmental factors. Besides protein pulses contain wide array of nutrients and antioxidants [2]. There are 11 types of pulses commonly consumed in the world, each having different amino acid composition. Green pea contains more amounts of lysine, alanine, cysteine and tyrosine; lentil contains more phenylalanine and serine; cowpea has more methionine and threonine and chickpea is rich in leucine, isoleucine and arginine. Hence adding variety in the diet is associated with reducing the risk of several chronic degenerative diseases including obesity. They had been one of the main ingredients in numerous cuisines all over of the world since ages. However, a paradigm shift has been observed in production and consumption trend of pulses and that may be due to the change in dietary habits, low digestibility and lack of market potential of the pulse products. In fact their use is affordable, sustainable and environment-friendly. To enhance the awareness about their role in meeting global challenge of nutrition insecurity and to consider the pulses as a sustainable seed of future, United Nations has declared 2016 as "International Year of Pulses" (IYP).

Pulses have also been exploited in various supplements owing to their rich profile of certain amino acids. Further their intrinsic structural conformation of proteins determines the functionality of the protein which supports development of value added foods, sports foods, dietetic foods and functional foods [3]. The presence of antinutritional factors in pulses, which are also considered as bioactive compounds, has found them a basic ingredient for health foods or nutraceuticals.
Inadequate amount of essential amino acids and denaturation of protein structure results in poor digestibility of proteins from pulses. Presence of less digestible protein fractions, high levels of insoluble fiber and high concentrations of antinutritional factors lowers the digestibility of protein in traditional diets of India; however, processing, cooking and germination improves the digestibility of pulses.

Largely pulse proteins are composed of storage proteins such as globulin and albumin. Globulin is about $60-80 \%$ globulins and albumin $15-25 \%$. Prolamins and glutelins are minor components in pulses. Prolamins have high concentration of proline and glutamine and glutelins have high concentration of methionine and cystine. Globulin is the major fraction of embryo and cotyledons of pulses. Globulins are relatively poor in sulphur-amino acids, hence pulse are poor in these amino acids. Albumins are high in lysine and sulphur containing amino acids [4]. Albumin contains enzymes and metabolically active compounds that are important during seed germination.

Each amino acid is associated with specific function in the body. Individual amino acids such as lysine and arginine have been found to be factors linked to growth hormone release in young children. Protein intake in early life is positively associated with height and weight. Hence children with stunting have lower serum level of essential amino acids particularly arginine, glycine and glutamine. Pulses are the potential ingredient for the intervention in such cases. Branch chain amino acids (BCAA) are reported to play significant role in sports people e.g. leucine in regulation of signalling pathways of muscle protein, valine in repair and isoleucine in muscle growth. Similarly each amino acid has specific function in different stages of life from infancy to elders.

\section{References}

1. Boye J, Zare F, Pletch A (2010) Pulse proteins: Processing, characterization, functional properties and applications in food and feed. Food Research International 43: 414-431.

2. Gilani GS, Cockel KA, Sepehr E (2005) Effects of antinutritional factors on protein digestibility and amino acid availability in foods. J AOAC Int 88 : 967-987.

3. Iqbal A, Khalil IA, Ateeq N, Khan MS (2006) Nutritional quality of important food legumes. Food Chemistry 97: 331-335.

4. Semba RD, Shardell M, Ashour SFA, Moaddel R, Trehan I, et al. (2016) Child Stunting is Associated with Low Circulating Essential Amino Acids. EBiomedicine 6: 246-252. 